\title{
Oblique Views in Radiographic Examination of Discrete Changes in Selected Diseases of the Digit in the Horse
}

\author{
J. ŠTERC, T. CRHÁKOVÁ \\ Clinic of Horse Diseases, Faculty of Veterinary Medicine, \\ University of Veterinary and Pharmaceutical Sciences, Brno \\ Received August 30, 2004 \\ Accepted June 6, 2005
}

\begin{abstract}
Šterc J., T. Crháková: Oblique Views in Radiographic Examination of Discrete Changes in Selected Diseases of the Digit in the Horse. Acta Vet Brno 2005, 74: 243-248.

In the present study, implication of oblique projections for examination of distal and proximal interphalangeal joints of forelimbs in a group of 43 randomly selected horses was demonstrated. Radiographic examinations of a total of 86 forelimbs were performed. The forelimbs were examined by radiography on lateromedial, dorsoproximal-palmarodistal views and also on dorsolateral-palmaromedial oblique and dorsomedial-palmarolateral oblique viewes of the limbs placed on a navicular block.

Evaluation of the radiographs obtained allowed diagnosis of the signs of degenerative joint disease (DJD) on distal interphalangeal joints of 27 limbs, signs of DJD on proximal interphalangeal joints of 17 limbs and signs of new formed bone on phalanges (not associated with a disease of distal or proximal interphalangeal joints) of 22 limbs. A total of 66 positive radiographic findings of the above mentioned disorders were diagnosed. Among those, positive radiographic findings of all the above mentioned disorders based on signs visible only on oblique views have been identified in 32 cases. In contrast, these radiographic changes based on signs visible either on lateromedial and/or dorsoproximal-palmarodistal view or both on lateromedial and/or dorsoproximal-palmarodistal and dorsolateral-palmaromedial and dorsomedialpalmarolateral viewes were identified in 34 cases. Difference in frequencies of detection of these disorders was not significant $(p \geq 0.05)$. It follows that as oblique as lateromedial and dorsoproximal-palmarodistal views were equally significant for identification of all the disorders mentioned above. Difference in frequencies of detection in cases with DJD of distal interphalangeal joint was highly significant $(p<0.01)$ and radiographic changes revealed on lateromedial and/or dorsoproximal-palmarodistal views were statistically more significant for identification of this disease. This difference in cases with DJD of proximal interphalangeal joint was not significant $(p \geq 0.05)$. This difference in cases with new bone formations on phalanges was highly significant $(p<0.01)$ and radiographic changes revealed on oblique viewes were statistically more significant for identification of this disorder. Therefore, we consider oblique views as necessary to be performed within radiographic examination of distal and proximal interphalangeal joints.
\end{abstract}

Pre-purchase examination, degenerative joint disease, new bone formation, coffin jonint, pastern joint

Radiographic examination plays a significant role in the examination of distal and proximal interphalangeal joints within pre-purchase examination as it can reveal discrete osteoarthritic changes without apparent clinical signs; they may induce lameness in a horse in the future and result in property-legal dispute between the seller and the buyer (Lauk 2002).

Degenerative joint disease (DJD) of distal parts of limbs is a common cause of lameness in horses of different breeds and age (Gallina 1982; Trotter et al. 1982). Various agents are involved in aetiology of this disease, however, always resulting in similar characteristic joint changes that may be revealed by careful clinical and radiographic examinations (Trotter et al. 1982; McIlwraith 2001). The role of radiographic examination plays a unique role in the diagnosis of the changes that is performed as a part of identification of 
lameness and usually follows immediately after clinical examination of the affected limb (Kawcak 2001; Stashak 2002).

Radiographic examination of DJD of distal interphalangeal joint in early cases is based on the detection of periarticular osteophytes on dorsoproximal border of distal phalanx, on dorsal surface of distal margin of middle phalanx, on palmar aspect of distal margin of middle phalanx and small irregularities and incongruencies of bone surfaces. Osteophytes on dorsoproximal border of navicular bone may also be an indicator of DJD, but should not be confused with enteseophytes. With more advanced disease, subchondral bone lucency may be visible at the dorsal aspect of the bone surface of distal phalanx joint, and there may be narrowing or unevenness of the joint space visible on dorsopalmar view (Butler et al. 2000).

In early cases of DJD of the proximal interphalangeal joint, small osteophytes on the dorsoproximal aspect of the middle phalanx are observed by radiographic examination. With the progression of the disease, there may be seen narrowing bone space, subchondral bone sclerosis and more extensive marginal osteophytes. With more advanced disease there may be narrowing of the joint space, subchondral sclerosis and more extensive marginal osteophyte formation. In advanced cases, there may be extensive new bone forming from the proximal aspect of the middle phalanx and the distal aspect of the proximal phalanx, attempting to bridge the proximal interphalangeal joint and create ankylosis (Butler et al. 2000).

Periarticular osteophytes, formed during DJD of distal and proximal interphalangeal joints should not be confused with radiographic findings of new bone formations which are not associated with this joint disease (Butler et al. 2000). These findings include:

- New bone formation on dorsal surface of proximal phalanx or on dorsal surface of middle phalanx which does not extend to the joint margins and is formed in association with periostitis caused by external trauma. These changes may be associated with lameness. New formed bone on dorsal surface of proximal margin of middle phalanx should be discriminated from complete or partial sagital fracture of middle phalanx.

- Irregular palisading of new formed bone on dorsal surface of diaphysis of middle phalanx. Smoothly outlined new formed bone can be seen in some cases. These changes are not usually associated with clinical signs and their aetiology is not known.

- Formation of new bone encircling the phalanges is not associated with the interphalangeal joints. Aetiology of these changes is not known either. It is usually associated with chronic lameness.

- Enteseophytes in the region of insertion of distal sesamoid ligaments that are likely formed due to acute or chronic stress of these ligaments. These may cause lameness initially while actively forming, but are not of long term significance. These enteseophytes should alert clinician to the possibility of soft-tissue injury.

A number of studies in the past dealt with radiographic imaging of distal parts of limbs in the horse; they were either anatomical studies or those describing respective diseases of this region (Trotter 1982; Ellis and Greenwood 1985; Smallwood et al. 1987; Dyson 1991). The above mentioned authors mostly used lateromedial (LM) or dorsopalmar or dosroproximal-palmarodistal (DP-PD) view for imaging of the structures of the toe. Other authors (Hertsch and Beerhues 1988; Park et al. 1996) consider oblique views, dorsomedial-palmarolateral oblique (DM-PL) and dorsolateral-palmaromedial oblique (DL-PM) views as essential to reveal certain signs of degenerative joint disease, particularly small osteophytes on dorsolateral and dorsomedial aspects of distal and proximal interphalangeal joints. It corresponds with the opinion of other authors who emphasize the use of oblique views particularly for radiographic examination of distal parts of the forelimbs within the pre-purchase examination of a horse (Lauk 2002; Van Oldruitenborgh-Oosterbaan 2002). 
The purpose of our study was to determine the rate of radiographic findings of DJD of distal or proximal interphalangeal joints and/or the finding of new formed bone on phalanges (non-associated with a disease of these joints) of limbs in a group of randomly selected horses. The study was also focused of the finding how many cases will be revealed on the basis of radiographic findings visible only on DL-PM and DM-PL views. The significance of oblique views in radiographic examination will be evaluated based on the results obtained.

\section{Materials and Methods}

For the investigation, a group of 43 randomly selected horses of both sexes in the age of 3 to 18 years of the following breeds was used: 35 warmblood, 5 thoroughbred, 2 cold-blooded horses and 1 hucul. Radiographic examination of the toes of forelimbs of the horses was performed. The examination was focused on radiographic findings of DJD of the distal and proximal interphalangeal joints and radiographic signs of newly formed bone on the phalanges without association with the disease of these joints.

Radiographic examination was performed using portable x-ray machine Gierth $80 \mathrm{HF}$ (with the output of $15 \mathrm{~mA}$ at $80 \mathrm{kV}$ ) at focal distance of $70 \mathrm{~cm}$ and exposure values $0.9 \mathrm{mAs}$ and $65-70 \mathrm{kV}$, without grid.

Radiographic examination of distal and proximal interphalangeal joints was performed on LM, DP-PD, DL-PM and DM-PL views. Examination of these joints in LM view was made on weight beared limb placed on flat block. The horizontal x-ray beam was centred $1 \mathrm{~cm}$ distal below the coronary band at a point midway between the most dorsal and most palmar aspects of the coronary band. The beam was aligned parallel to a line drawn across the bulbs of the heel.

Radiographs of the distal and proximal interphalangeal joint in were obtained with the toe of the foot placed on a navicular block using the DP-PD, DL-PM and DM-PL views. Radiographs of a limb placed on a navicular block using DP-PD view, the horizontal x-ray beam was centred approximatelly $2 \mathrm{~cm}$ proximal to the coronary band at the midline of the foot and fell on the cassette placed palmarly behind the toe. Radiographs of a limb placed on a navicular block using DL-PM and DM-PL views, the horizontal x-ray beam was centred in the coronary band at a point midway between the most dorsal and most palmar aspects of the coronary band. X-ray beam fell on the cassette placed behind the toe perpendicularly to it. Each of the oblique views was performed twice as follows: $\mathrm{X}$ ray beam and the dorsopalmar axis of the toe angled firstly $60^{\circ}$ and secondly $45^{\circ}$. The views will be further designated as DL-PM60, DL-PM45 and DM-PL60, DM-PL45. A template of a sector was used for exact determination of $\mathrm{x}$-ray beam centring.

All radiographs obtained were independently evaluated by each of the two authors of the present study; all x-ray findings of DJD of distal interphalangeal joint, DJD of proximal interphalangeal joint and x-ray findings of new bone formations on phalanges not associated with the joint disease were registered. One evaluator's findings were compared with those obtained by the other one; in case of a difference between their results, they were discussed and subsequently coincidently explained. Based on the findings obtained, we assessed the rates of limbs with a positive $\mathrm{x}$-ray finding of DJD of distal interphalangeal joint signs, DJD of proximal interphalangeal joint signs and positive $\mathrm{x}$-ray finding of new bone formations on phalanges non-associated with the joint disease. We further evaluated the rates of cases with DJD of distal interphalangeal joint, DJD of proximal interphalangeal joint and positive finding of new bone formations on phalanges apparently manifested using:

- LM and/or DP-PD view only

- LM and/or DP-PD views and using DL-PM and/or DM-PL views

- DL-PM and/or DM-PL view only.

Based on these results, frequency of identification of each of the diseases determined by radiographic changes apparent only on oblique views was compared with frequency of detection based on radiographic changes apparent on LM and/or DP-PD views or by both LM and/or DP-PD and oblique views concurrently. The comparison was performed by the test of differences between two relative values $\left(\chi^{2}\right)$.

\section{Results}

During the investigation, in 31 of 43 examined horses, radiographic signs of DJD of the distal interphalangeal joint or DJD of proximal interphalangeal joint or new bone formation on phalanx not associated with the disease of the distal or proximal interphalangeal joint were detected. The count of positive radiographic findings and their percentages detected on respective views are summarized in Table 1. Evaluation of radiographic findings on respective limbs showed that DL-PM60 and DM-PL60 view findings corresponded to those of DL-PM45 and DM-PL45 views, respectively.

By comparison of the cases with DJD of distal interphalangeal joint manifested apparently only on oblique views with the number of cases visible only on LM and/or DP-PD view or 
both on LM and/or DP-PD and on oblique views, we detected that the difference between frequencies of identification was highly significant $(p<0.01)$.

By comparison of the cases with DJD of proximal interphalangeal joint manifested apparently only on oblique views with the number of cases of DJD of proximal interphalangeal joint manifested with signs visible either only on LM and/or DP-PD view or on both LM and/or DP-PD and oblique views we found out that the difference between frequencies of detection was not significant $(p \geq 0.05)$.

By comparison of cases with positive radiographic finding of new bone formations on phalanges manifested by signs visible only on oblique views with the number of cases with positive radiographic finding of new bone formations on phalanges manifested by signs visible either only on LM and/or DP-PD or both on LM and/or DP-PD and oblique views, we found out that the difference between frequencies of detection was highly significant $(p<0.01)$.

By comparison of all cases of the above mentioned disorders manifested by signs visible only on oblique views with the number of cases of these disorders manifested either only on LM and/or DP-PD view or both on LM and/or DP-PD and oblique views we found out that the difference between frequencies of detection was not significant $(p \geq 0.05)$.

Table 1. Positive radiographic findings (DJD of distal and proximal interphalangeal joints and new formed bone) on respective views

\begin{tabular}{|c|c|c|c|c|}
\hline & \multicolumn{4}{|c|}{ Rates of positive x-ray findings } \\
\hline View & $\begin{array}{c}\text { DJD of distal } \\
\text { interphal. joint }\end{array}$ & $\begin{array}{c}\text { DJD of prox. } \\
\text { interphal. joint }\end{array}$ & $\begin{array}{c}\text { New formed } \\
\text { bone }\end{array}$ & $\begin{array}{c}\text { Positive x-ray } \\
\text { findings in total }\end{array}$ \\
\hline Total & $27(100 \%)$ & $17(100 \%)$ & $22(100 \%)$ & $66(100 \%)$ \\
\hline LM, DP-PD only & $18(66.7 \%)$ & $4(23.5 \%)$ & $1(4.5 \%)$ & $23(34.8 \%)$ \\
\hline $\begin{array}{c}\text { LM, DP-PD } \\
\text { and oblique views }\end{array}$ & $5(18.5 \%)$ & $2(11.8 \%)$ & $4(18.2 \%)$ & $11(16.7 \%)$ \\
\hline Oblique views only & $4(14.8 \%)$ & $11(64.7 \%)$ & $17(77.3 \%)$ & $32(48.5 \%)$ \\
\hline
\end{tabular}

\section{Discussion}

The question whether to include oblique views as obligatory in conventional radiographic examination of distal and proximal interphalangeal joints within pre-purchase examination of a horse is the matter of continuous discussion (Lauk 2002; Van OldruitenborghOosterbaan 2002). It is common in practice that radiographic examination includes only LM and DP-PD views wherever it may be performed as the pre-purchase examination or for diagnosis of lameness. It is well known that radiographic examination on oblique view must be performed to reveal certain signs of DJD of distal interphalangeal joint (Herts ch and Beerhues 1988). Therefore some authors consider oblique views of distal parts of forelimbs as necessary to be performed within radiographic examination (Lauk 2002; Van Oldruitenborgh-Oosterbaan 2002).

It follows from Table 1 that DJD of distal interphalangeal joint was diagnosed on 4 limbs based on radiographic signs visible only on oblique views. In contrast, DJD of distal interphalangeal joint was diagnosed on 23 limbs based on radiographic findings visible either only on LM and/or DP-PD view or both on LM and/or DP-PD and oblique views. That difference in frequencies of findings was highly significant $(p<0.01)$. It follows that radiographic changes revealed on LM and/or DP-PD views were statistically more significant for detection of DJD of distal interphalangeal joint.

Table 1 shows that DJD of proximal interphalangeal joint was diagnosed on 11 limbs based on radiographic signs visible only on oblique views. On the contrary, DJD of 
proximal interphalangeal joint on 6 limbs was diagnosed based on radiographic signs visible either only on LM and/or DP-PD views or both on LM and/or DP-PD and oblique views. That difference in frequencies of findings was not significant $(p \geq 0.05)$. That means that radiographic changes revealed both on oblique and LM and/or DP-PD views were of the same statistical significance for identification of DJD of proximal interphalangeal joint.

Positive radiographic finding of new bone formations on phalanges not associated with joint disorders was revealed on 17 limbs based on changes visible only on oblique views. In contrast, this positive radiographic finding was revealed on 5 limbs based on changes visible either only on LM and/or DP-PD views or on both LM and/or DP-PD views and oblique views. The difference in frequencies of detection was highly significant $(p<0.01)$. It means that radiographic changes revealed on oblique views were statistically more significant for identification of new bone formations on phalanges.

A total of 66 positive radiographic findings of the above mentioned disorders have been revealed. Among those, positive radiographic findings of these disorders were identified based on signs visible only on oblique views in 32 cases. In contrast, these disturbances were identified based on signs visible only on LM and/or DP-PD views or on both LM and/or DP$\mathrm{PD}$ and oblique views in 34 cases. The difference in frequencies of detection of the above mentioned disturbances was not significant $(p \geq 0.05)$. That implies that both oblique views and LM and/or DP-PD views were equally statistically significant for identification of all these disturbances.

Based on the results of the present study we are inclined to the opinion of Hertsch and Beerhues (1988), Park (1996), Lauk (2002) and Van Oldruitenborgh-Oosterbaan (2002) who regard oblique views as necessary within radiographic examination of distal parts of limbs.

\section{Význam šikmých projekcí při rentgenologické diagnostice diskrétních změn při některých onemocněních prstu u koně}

V naší studii byl prokázán na souboru 43 náhodně vybraných koní význam šikmých projekcí při vyšetření kopytního a korunkového kloubu hrudních končetin. Celkem bylo rentgenologicky vyšetřeno 86 hrudních končetin. Tyto končetiny byly rentgenologicky vyšetřeny v lateromediální, dorzoproximálně-palmárodistální projekci a dále v šikmých projekcích zhotovených na končetině umístěné ve střelkovém bloku.

Vyhodnocením získaných rentgenogramů byly diagnostikovány na 27 končetinách příznaky degenerativního kloubního onemocnění (dále jen DJD) na kopytním kloubu, na 17 končetinách příznaky DJD na korunkovém kloubu a na 22 končetinách formace novotvořené kosti na článcích prstu, které nesouvisely s onemocněním kopytního nebo korunkového kloubu. Celkem tedy bylo diagnostikováno 66 pozitivních rentgenologických nálezů výše uvedených změn. Z toho byly ve 32 případech identifikovány pozitivní rentgenologické nálezy všech výše uvedených změn na základě příznaků viditelných jen na šikmých projekcích. Naproti tomu byly ve 34 případech identifikovány tyto rentgenologické změny na základě příznaků viditelných bud jen na lateromediálních a/nebo dorzoproximálně-palmarodistálních projekcích nebo na lateromediálních a/nebo dorzoproximálně-palmarodistálních i šikmých projekcích. Rozdíl mezi četnosti záchytu těchto změn nebyl významný ( $p \geq 0,05)$. To znamená, že pro záchyt všech výše uvedených změn byly stejně významné jak šikmé, tak lateromediální a dorzoproximálněpalmarodistální projekce. $\mathrm{V}$ př́ípadě degenerativního kloubního onemocnění kopytního kloubu byl tento rozdíl v četnosti záchytu vysoce významný $(p<0,01) \mathrm{s}$ tím, že pro záchyt tohoto onemocnění byly významnější rentgenologické změny odhalené na lateromediální a/nebo dorzoproximálně-palmárodistální projekci. V případě degenerativního kloubního 
onemocnění korunkového kloubu nebyl tento rozdíl významný ( $p \geq 0,05)$. V případě nálezu formací novotvořené kosti na článcích prstů byl tento rozdíl v četnosti záchytu vysoce významný $(p<0,01)$ s tím, že pro záchyt těchto změn byly významnější rentgenologické změny odhalené na šikmých projekcích. Proto považujeme za nezbytné při rentgenologickém vyšetření kopytního a korunkového kloubu provádět i vyšetření v šikmých projekcích.

\section{References}

BUTLER JA, COLLES CM, DYSON SJ, KOLD SE, POULOS PW 2000: Foot, Pastern and Fetlock. In: Butler JA, Colles CM, Dyson SJ, Kold SE, Poulos PW Clinical Radiology of the Horse. London, Blackwell Science Ltd, pp. 27-130.

DYSON S 1991:Lameness due to pain associated with the distal interphalangeal joint: 45 cases. Equine Vet J 23: $128-135$

ELLIS DR, GREENWOOD R 1985: Six cases of degenerative joint disease of the proximal interphalangeal joint of young thoroughbreed. Equine Vet J 17: 66-68

GALLINA AM 1982: Bone and Joint Pathology. Equine Med Surg 2: 981

HERTSCH B, BEERHUES U 1988: Der Wendeschmerz als Symptom bei der Lahmheitsuntersuchung des Pferdes - pathomorphologische, röntgenologische und klinische Untersuchungen. Pferdeheilkunde 4: 12-22

KAWCAK CHE 2001: Current and future diagnostic means to better characterize osteoarthritis in the horseimaging. AAEP Proceedings 47: 164-170

LAUK HD 2002: Kaufuntersuchung - die ständige Herausforderung. Brauchen wir einen erweiterten Standard? Pferdeheilkunde 3: 212-216

McILWRAITH CW 2001: Disease processes of synovial membrane, fibrous capsule, ligaments and articular cartilage. AAEP Proceedings 47:142-156

PARK RD, STEYN PF, WRIGLEY RH 1996: Imaging Techniques in the Diagnosis of Equine Joint Disease. In: McIlwraith CW Joint Disease in the Horse. Philadelphia, W. B. Saunders Company, p.145.

SMALLWOOD JE, STEVEN MS, HOLLADAY D 1987: Xerographic anatomy of the equine digit and metacarpophalangeal region. Vet Radiol Ultrasound 28: 166-173

STASHAK T S 2002: Lamenness; Part I: The Foot, and Part II: The Pastern. In: Stashak TS: Adams' lamenness in horses. Philadelphia; Lippincott Williams and Wilkins, pp. 645-767.

TROTTER G, McILWRAITH CW, NORRDIN RW, TURNER A 1982: Degenerative joint disease with osteochondrosis of the proximal interphalangeal joint in young horses. J Am Vet Med Assoc 180: 1312-1318

Van OLDRUITENBORGH-OOSTERBAAN MMS 2002: Die Tierärztliche Kaufuntersuchung von Pferden in den Niederlanden. Pferdeheilkunde 3: 243-252 